\title{
Thrombolysis-resistant intracranial clot
}

Lucas Di Meglio, MD, Jean Philippe Desilles, MD, PhD, Mikael Mazighi, MD, PhD, and Benoît Ho-Tin-Noé, PhD Neurology ${ }^{\circledR}$ 2018;90:1075. doi:10.1212/WNL.0000000000005645

\section{Correspondence}

Dr. Di Meglio

lucas.dimeglio@

gmail.com or Dr. Ho-Tin-Noé

benoit.ho-tin-noe@inserm.fr

Figure Macroscopic and ultrastructural aspect of an intracranial thrombolysis-resistant clot

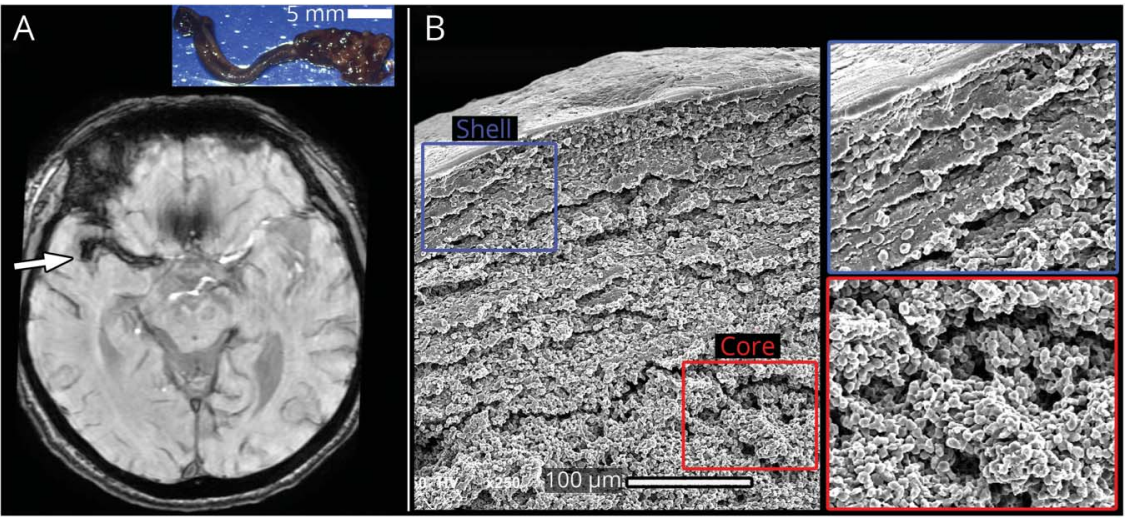

Susceptibility-weighted imaging MRI sequence shows a thrombus occluding the first segment of the right $M C A(A$, arrow). Analysis of the extracted thrombolysis-resistant clot ( $A$, inset) by scanning electron microscopy (B) reveals a thick compact outer shell surrounding a loose erythrocyte-rich core.

A 57-year-old man presented with symptoms of right middle cerebral artery (MCA) stroke (NIH Stroke Scale score [NIHSS] 19) including eyes and head deviation, proportional left hemiplegia, left hemianopsia, and left hemispatial neglect. MRI showed occlusion of the first segment of the right MCA (figure). Thrombolysis was initiated 3.5 hours after onset. First angiographic acquisition 1.5 hours later showed persistent occlusion. Successful recanalization was obtained by aspiration thrombectomy 6 hours after onset.

Scanning electron microscopy analysis of the clot (figure) revealed a thick compact outer shell, which might participate in thrombolysis resistance. Despite the initial radio-clinical mismatch, NIHSS at 24 hours remained stable at 19.

\section{Author contributions}

Lucas Di Meglio: acquisition of data, analysis and interpretation of data. Jean Philippe Desilles: study concept, critical revision of manuscript for intellectual content. Mikael Mazighi: critical revision of manuscript for intellectual content, study supervision. Benoit Ho-Tin-Noé: study concept, critical revision of manuscript for intellectual content, analysis and interpretation of data.

\section{Study funding}

This work was supported by INSERM, La Fondation pour la Recherche sur les AVC (grant FRAVC-003), and La Fondation pour la Recherche Médicale (grant DPC20171138959). Dr. Di Meglio is the recipient of a $\mathrm{PhD}$ grant from La Fondation de L'Avenir.

\section{Disclosure}

The authors report no disclosures relevant to the manuscript. Go to Neurology.org/N for full disclosures. 


\section{Neurology}

\section{Thrombolysis-resistant intracranial clot}

Lucas Di Meglio, Jean Philippe Desilles, Mikael Mazighi, et al. Neurology 2018;90;1075

DOI 10.1212/WNL.0000000000005645

\section{This information is current as of June 4, 2018}

\section{Updated Information \&} Services

\section{Citations}

Permissions \& Licensing

Reprints including high resolution figures, can be found at: http://n.neurology.org/content/90/23/1075.full

This article has been cited by 1 HighWire-hosted articles: http://n.neurology.org/content/90/23/1075.full\#\#otherarticles

Information about reproducing this article in parts (figures,tables) or in its entirety can be found online at:

http://www.neurology.org/about/about_the_journal\#permissions

Information about ordering reprints can be found online:

http://n.neurology.org/subscribers/advertise

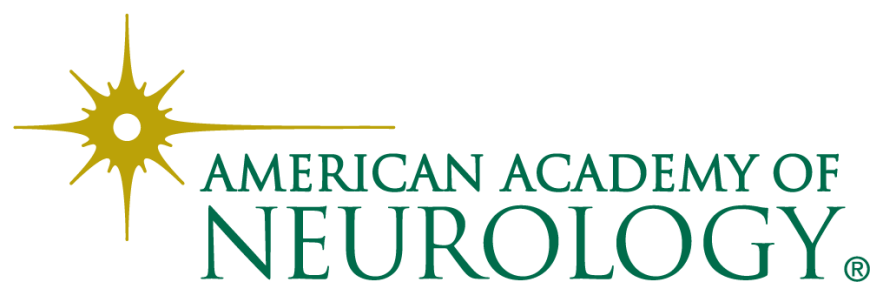

